\title{
Dry Matter and Nitrogen Accumulation During Vegetative and Grain Filling of Lentil (Lens culinaris Medic.) as Affected by Nitrogen Rates
}

\author{
Nurdilek GULMEZOGLU*, Nihal KAYAN \\ Eskisehir Osmangazi University, Faculty of Agriculture, Department of Field Crops, 26160 \\ Eskisehir,Turkey;dgulmez@ogu.edu.tr (*correspondingauthor)
}

\begin{abstract}
This research aimed to determine the effect of different levels of nitrogen $(\mathrm{N})$ on the growth, yield and the $\mathrm{N}$ accumulation of lentil plants grown under rain-fed conditions. The two-year field experiments with lentil were arranged in a randomised complete block design. Nitrogen was applied at four rates $\left(0,20,40\right.$ and $\left.60 \mathrm{~kg} \mathrm{ha}^{-1}\right)$ and all of the plots received half of the $\mathrm{N}$ rates before sowing in October and the remaining $\mathrm{N}$ rate in spring. The plants were harvested in the following stages: the first multifoliate leaf unfolding at the fifth node (V5) full seed or seed on nodes 10-13 that fill pod cavities (R6) and maturity (R8). The dry weight and N concentration of the shoot (leaf+stem), pod wall, and seed were then measured. It has been found that $\mathrm{N}$ application significantly affected the lentil characteristics. The maximum biomass accumulation and $\mathrm{N}$ accumulation were obtained at $\mathrm{R} 6$, and the $\mathrm{N}$ fertiliser had a positive effect on the seed weight and $\mathrm{N}$ accumulation. It can be suggest that $20 \mathrm{~kg} \mathrm{~N} \mathrm{ha}^{-1}$ will increase the per-plant dry matter and $\mathrm{N}$ accumulation of the seeds under rain-fed conditions.
\end{abstract}

Keywords: dry matter, growth stage, lentil, nitrogen accumulation, nitrogen fertiliser, seed filling stage

\section{Introduction}

Legumes crops are important agricultural crops worldwide grown primarily for their high seed protein content (Malhi et al., 2007; Niri et al., 2010; Soltani et al., 2006; Togay et al., 2005; Walley et al., 2007). One important benefit of legume crop production is the ability of these crops to form symbiotic associations with nitrogen (N)-fixing Rhizobium bacteria, thereby reducing their dependence on inorganic $\mathrm{N}$ fertilisers. It has long been recognised that $\mathrm{N}$ fertiliser represents the main economic and energy costs of continuous cropping systems. Generally, it is assumed that a well-inoculated legume crop can fix sufficient quantities of $\mathrm{N}$ to eliminate the need for $\mathrm{N}$ fertiliser input during the growth season of the legume crop (van Kessel and Hartley, 2000). However, legume crops have high grain protein contents in their grain; thus, the net export of $\mathrm{N}$ to grain is frequently high and often exceeds the total amount of fixed $\mathrm{N}$ in the biomass (Beck et al., 1991).

Being a legume, lentil (Lens culinaris Medic.) can form symbiotic associations with Rhizobium bacteria and, under favourable conditions, biologic $\mathrm{N}$ fixation by lentil can reach as high as $20 \mathrm{~kg} \mathrm{~N}^{-1} \mathrm{yr}^{-1}$ (McNeil and Materne, 2007). The application of a suitable amount of $N$ fertiliser in lentil has been reported to increase the dry matter and $\mathrm{N}$ uptake (Malhi et al., 2007; Niri et al., 2010; Togay et al., 2005). Indeed, increased rates of fertilizer application have steadily increase, the dry matter, seed yield, and $\mathrm{N}$ accumulation in crops. However, information on the accumulation and distribution of biomass and $\mathrm{N}$ accumulation in lentil plants during the growing season under rain-fed conditions is lacking. Therefore, the objective of this study was to determine the effects of different levels of $\mathrm{N}$ on the plant growth, seed yield, and $\mathrm{N}$ accumulation of lentil grown under rain-fed conditions.

\section{Materials and methods}

Two-year field experiments using lentil were established in 2006-2007 and 2007-2008 in the fields of the Faculty of Agriculture in Eskisehir, Turkey (39 $48^{\prime} \mathrm{N} ; 30^{\circ} 31^{\prime} \mathrm{E}$ ). The soil of the experimental fields was slightly alkaline during the two years. The soil of the research area in the first year had a low water-holding capacity, was alkaline $(\mathrm{pH} 8.1)$ and calcareous $\left(65 \% \mathrm{CaCO}_{3}\right)$, and contained a low amount of organic matter (1.2\%). The $\mathrm{P}_{2} \mathrm{O}_{5}$ and $\mathrm{K}_{2} \mathrm{O}$ contents were sufficient in the first year; however, in the second year, the organic matter was at a medium level, the $\mathrm{P}_{2} \mathrm{O}_{5}$ and $\mathrm{K}_{2} \mathrm{O}$ contents were low, and the soil was loamy in texture. The long-term (1975-2007) total rainfall and average temperature of the location are $289.7 \mathrm{~mm}$ and $8.4^{\circ} \mathrm{C}$, respectively (Tab. 1 ). The weather conditions during the two years were different. During the 2006-2007 growing season, there was quite a lot of rainfall during the period of seed filling. In contrast, the 2007-2008 season was hotter during the seed filling stage.

The experimental design was a randomised complete block design with four replications, and the experimental plots measured $5.4 \mathrm{~m}^{2}$. The lentil cultivar, 'Kay1-91', was used as the research material. The seeds were sown by hand 
Tab. 1. Monthly precipitation and temperature values for September through June in 2006-2007 and 2007-2008 and an extended period (30 years) in Eskisehir

\begin{tabular}{|c|c|c|c|c|c|c|}
\hline & \multicolumn{3}{|c|}{ Total rainfall $(\mathrm{mm})$} & \multicolumn{3}{|c|}{ Mean temperature $\left({ }^{\circ} \mathrm{C}\right)$} \\
\hline & Long period & $2006 / 07$ & $2007 / 08$ & Long period & $2006 / 07$ & $2007 / 08$ \\
\hline September & 93.0 & 0.0 & 15.4 & 16.7 & 16.6 & 17.7 \\
\hline October & 47.5 & 19.1 & 16.4 & 11.7 & 12.6 & 12.6 \\
\hline November & 16.8 & 91.7 & 32.9 & 5.6 & 3.9 & 4.9 \\
\hline December & 6.8 & 46.1 & 34.7 & 1.4 & -0.7 & 0.6 \\
\hline January & 42.2 & 13.1 & 28.6 & -0.4 & 0.0 & -3.5 \\
\hline February & 14.2 & 2.7 & 23.0 & 0.7 & 1.5 & 0.0 \\
\hline March & 24.0 & 29.9 & 26.0 & 4.6 & 5.4 & 8.4 \\
\hline April & 25.0 & 38.1 & 41.1 & 9.6 & 7.5 & 11.5 \\
\hline May & 65.6 & 14.4 & 38.9 & 14.9 & 17.8 & 14.3 \\
\hline June & 58.6 & 2.8 & 22.7 & 19.0 & 20.8 & 20.2 \\
\hline Total & 257.9 & 393.7 & 289.7 & & & \\
\hline Mean & & & & 8.38 & 8.54 & 8.67 \\
\hline
\end{tabular}

on October $9^{\text {th }}$ in the first year and on October $2^{\text {nd }}$ in the second year at a depth of $5 \mathrm{~cm}$, with 6 rows and a row spacing of $30 \mathrm{~cm}$. Phosphorus fertilisation was carried out at sowing $\left(60 \mathrm{~kg} \mathrm{P}_{2} \mathrm{O}_{5} \mathrm{ha}^{-1}\right)$ in the form of triple superphosphate (0-45-0). Nitrogen fertilisation was applied as ammonium sulphate (21-0-0-24) at four rates $(0,20,40$ and $60 \mathrm{~kg} \mathrm{ha}^{-1}$ ), and all of the plots received half of the $\mathrm{N}$ before sowing and the remaining $\mathrm{N}$ in the spring when plants were at the stage of the second bifoliate leaf unfolding at the fourth node (V4) (Erskine et al., 1990).

Plants in the stage of the first multifoliate leaf unfolding at the fifth node (V5), full seed or seed on nodes 10-13 that filled the pod cavities (R6) and maturity (R8) were harvested. At R6 and R8, the dry weight and N concentration of the shoot (leaf+stem), pod wall, and seed were measured. The sampled material was dried at $65^{\circ} \mathrm{C}$ to achieve a constant weight. All of the $\mathrm{N}$ measurements were total $\mathrm{N}$ and were based on the Kjeldahl method. The $\mathrm{N}$ accumulation was calculated by multiplying the dry weight of the shoot, pod wall, and seed by the $\mathrm{N}$ concentration contained within them. The data were subjected to an analysis of variance (ANOVA), and the means were compared by the least significant difference (LSD) at confidence level using MSTAT-C computer programs.

\section{Results and discussion}

The analysis of the variance of the data for the influence of $\mathrm{N}$ applications on the dry matter, $\mathrm{N}$ concentration, and $\mathrm{N}$ accumulation at different growth stages of lentil is shown in Tab. 2 . The growth stage, $\mathrm{N}$ rate, and the interaction of the growth stage and $\mathrm{N}$ rate significantly affected the dry weight of the shoot dry matter $(\mathrm{P}<0.01)$, pod wall $(\mathrm{P}<0.01)$, and seed per plant $(\mathrm{P}<0.01)$. There was a decrease in the dry weight of the shoot and pod wall and an increase in the dry weight of the seed with the growth stage and seed yield per plant during the second year due to the weather conditions (Tab. 3). The observed difference may be explained, in part, by the slightly warmer temperatures (when averaged throughout the crop cycle) during the second year. However, it is more likely due to the higher rainfall (March to June $-128.7 \mathrm{~mm}$ ) after topdressing in the second year, especially during the stage of reproductive growth, which encouraged continued branch production after flowering. A high rainfall and high temperature throughout the grain-filling period can have a significant effect on the seed weight. Such a dramatic difference in the dry weight of the seeds per plant under disordered weather conditions has previously been observed

Tab. 2. Results of analysis of variance (mean squares) to analyse the dry matter, $\mathrm{N}$ concentration and $\mathrm{N}$ accumulation of lentil at different growth stages

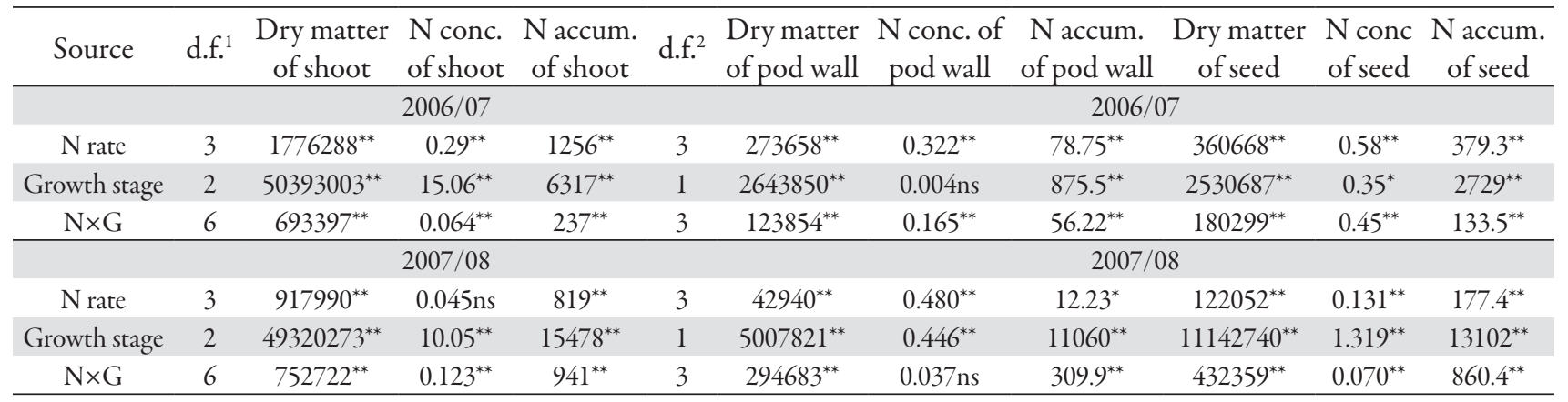

d.f.: degree of freedom; ${ }^{1}$ sampling time is V5, R6 and R8; ${ }^{2}$ sampling time is R6 and R8; ${ }^{*}$ significant at 5\%; ${ }^{*}$ significant at $1 \%$; ns-non-significant 
198

in lentil (Whitehead et al., 2000) and safflower (Dordas and Sioulas, 2009). The relationship between the amount of plant biomass amount and seed yield for flax has also been reported to be influenced by weather conditions or genotype-environment interactions (Casa et al., 1999; Diepenbrock et al., 1995).

The shoot and pod wall weight were the highest at the filled pod cavities (R6). The total above ground biomass increased after anthesis in both years. There was a decrease in the total dry matter between R6 and R8, which has previously been reported in wheat (Papakosta and Gagianas, 1991) and safflower (Dordas and Sioulas, 2009). Nitrogen shortage and $\mathrm{N}$ excess can affect assimilate partitioning between the vegetative and reproductive organs, and dry matter partitioning (depending on the sink number, sink activity and seed number) is strongly associated with assimilate availability at flowering (Dordas and Sioulas, 2009). Thus, the high dry matter accumulation before maturity has an effect on the yield volume.

The dry matter accumulation of the shoot varied according to the $\mathrm{N}$ levels and growing stage (Tab. 3). The dry weight of the shoot during the V5 and R6 stages increased under $40 \mathrm{~kg} \mathrm{~N} \mathrm{ha}{ }^{-1}$ in the first year and $20 \mathrm{~kg} \mathrm{~N} \mathrm{ha}^{-1}$ in the second year and decreased under $60 \mathrm{~kg} \mathrm{~N} \mathrm{ha}^{-1}$ in both years. Nevertheless, the dry matter of the shoot at R8 was not changed with the increasing $\mathrm{N}$ rate even when there was no difference between the control and $\mathrm{N}$ treatment plots in the dry matter of the shoot for the first year. The effect of the shoot on the total dry weight of the plant at R6 and R8 was 84 and $72 \%$ under $60 \mathrm{~kg} \mathrm{~N} \mathrm{ha}^{-1}$, respectively, in the first year and $71 \%$ under $20 \mathrm{~kg} \mathrm{~N} \mathrm{ha}^{-1}$ and $51 \%$ under $60 \mathrm{~kg} \mathrm{~N} \mathrm{ha}^{-1}$ in the second year. The dry weight of the pod wall was the highest in the control plot at R6 and $\mathrm{R} 8$ in the first year and at $\mathrm{R} 6$ under $40 \mathrm{~kg} \mathrm{~N} \mathrm{ha}^{-1}$ and at $\mathrm{R} 8$ under $20 \mathrm{~kg} \mathrm{~N} \mathrm{ha}^{-1}$ in the second year. Interestingly, the contribution of the pod wall to the total dry weight per plant at R6 and R8 for both years occurred in the control plot at R6 (20-22\%) and in the $20 \mathrm{~kg} \mathrm{~N}^{-1} \mathrm{a}^{-1}$ plot at R8. The seed weight per plant was the highest at R6 and R8 in the control in the first year (Tab. 3). However, the seed weight per plant, as was also the case with the pod wall, was the highest under $40 \mathrm{~kg} \mathrm{~N} \mathrm{ha}^{-1}$ (after the control) at $\mathrm{R} 6$ and $20 \mathrm{~kg} \mathrm{~N} \mathrm{a}^{-1}$ at R8. The dry weight of the whole plant was the highest under $40 \mathrm{~kg} \mathrm{ha}^{-1}$ in the first year and $60 \mathrm{~kg} \mathrm{ha}^{-1}$ in the second year.

The results of $\mathrm{N}$ application showed that although the dry matter of the shoot was the highest in the V5 and R6 stages at an application of $40 \mathrm{~kg} \mathrm{~N} \mathrm{ha}^{-1}$, there was no difference in shoot weight between control and $40 \mathrm{~kg} \mathrm{~N} \mathrm{ha}^{-1}$ at harvest time under the higher rainfall conditions in the first year. It was found that $\mathrm{N}$ application did not increase in dry weight of the seed per plant at harvest time in the first year; however, the ration in the total plant weight of the seed yield per plant was affected by $20 \mathrm{~kg} \mathrm{~N} \mathrm{ha}^{-1}$ rate (36 and 41\%) in both years. Previous studies have stated that the grain yield was increased by increasing the rate of $\mathrm{N}$ application in lentil (Niri et al., 2010; Togay et al., 2005).

The growth stage, $\mathrm{N}$ rate and interaction of the growth stage and the $\mathrm{N}$ rate significantly affected the $\mathrm{N}$ concentration of the shoot, pod wall, and seed per plant $(\mathrm{P}<0.01)$, and only the effect of the $\mathrm{N}$ rate and the interaction of the $\mathrm{N}$ concentration on the shoot and pod wall were not significant $(\mathrm{P}>0.05)$ (Tab. 2). The highest $\mathrm{N}$ concentration in the shoot occurred at V5, whereas the highest $\mathrm{N}$ concentration in the pod wall and seed was at R6 (Tab. 4). The $\mathrm{N}$ concentration of the shoot at V5 was higher in the plots with applied $\mathrm{N}$ than in the control plot during the two-year period. The $\mathrm{N}$ concentration of the shoot during the vegetative period (V5) was 31.93-39.91 $\mathrm{mg} \mathrm{g}^{-1}$, which is consistent with the values reported for other legumes. For instance, Turpin et al. (2002) found an initial value of $30 \mathrm{mg} \mathrm{g}^{-1}$ for the stem $\mathrm{N}$ concentration in faba bean.

The $\mathrm{N}$ concentration of the pod wall did not increase compared with the control at R6 for both years or at R8 in the second year (Tab. 4). Whereas the $\mathrm{N}$ concentration of the seed was the highest under $20 \mathrm{~kg} \mathrm{~N}^{-1}$ at $\mathrm{R} 6$ in the first year and $60 \mathrm{~kg} \mathrm{~N} \mathrm{ha}^{-1}$ at $\mathrm{R} 8$ in the second year, the highest $\mathrm{N}$ concentration in the seed was found under 60 $\mathrm{kg} \mathrm{N} \mathrm{ha}{ }^{-1}$ at $\mathrm{R} 6$ and $\mathrm{R} 8$ for both years. The $\mathrm{N}$ concentration of the seed declined during the seed-filling period from R6 to R8. This decrease in the $\mathrm{N}$ concentration of the seed is consistent with the values reported for chickpea by Saxena (1984) and Soltani et al. (2006), who stated that the total $\mathrm{N}$ concentration of grain continues to increase as the grain grows but that the $\mathrm{N}$ decreases because starch accumulates faster than $\mathrm{N}$. A similar decline in the $\mathrm{N}$ concentration of grain has been found by Lhuillier-Soundele et al. (1999) in pea and soybean (Hayati et al., 1995), whereas a relatively constant grain $\mathrm{N}$ concentration has been reported for soybean, cowpea, and mungbean (Muchow et al., 1993).

The $60 \mathrm{~kg} \mathrm{~N} \mathrm{ha}^{-1}$ rate resulted in the highest $\mathrm{N}$ concentration in the stem, pod wall, and seed during the two years. The effect of the $\mathrm{N}$ fertiliser on the $\mathrm{N}$ concentration of the shoot, pod wall, and seed was significantly positive. Nitrogen is involved in vital plant functions, such as photosynthesis and protein formation (Marschner, 1995). Growth parameters, including the leaf area index, leaf photosynthesis, and the $\mathrm{N}$ concentration of plant tissue, may decrease due to unsatisfactory $\mathrm{N}$ availability (Caliskan $e t$ al., 2008). The results obtained in this study indicated that the $\mathrm{N}$ fertilisation had a positive effect on the $\mathrm{N}$ concentration of the seed, a finding in agreement with Niri et al. (2010).

Nitrogen fertiliser, the growth stage, and the interaction of the $\mathrm{N}$ fertiliser and growth stage were significant in the $\mathrm{N}$ accumulation of the shoot, pod wall, and seed (Tab. 2); however, the accumulation of $\mathrm{N}$ in different plant parts varied between the years (Tab. 5). The accumulation was higher in the second year for all of the $\mathrm{N}$-application plots due to the weather conditions: the dry matter accumulation and $\mathrm{N}$ concentration were low, affecting the accu- 
Tab. 3. Dry matter (mg/plant) of lentil plants at different growth stages during 2006-2007 and 2007-2008

\begin{tabular}{|c|c|c|c|c|c|c|c|c|c|c|c|c|c|c|c|}
\hline \multicolumn{3}{|c|}{ Vegetative $^{1}$} & \multicolumn{5}{|c|}{ Filled pod cavities $^{2}$} & \multicolumn{8}{|c|}{ Maturity $^{3}$} \\
\hline $\begin{array}{l}\text { N rate } \\
\left(\mathrm{kg} \mathrm{ha}^{-1}\right)\end{array}$ & Shoot & Shoot & $\begin{array}{l}\text { Ration in total } \\
\text { plant (\%) }\end{array}$ & $\begin{array}{l}\text { Pod } \\
\text { wall }\end{array}$ & $\begin{array}{l}\text { Ration in } \\
\text { total (\%) }\end{array}$ & $\begin{array}{l}\text { Seeds per } \\
\text { plant }\end{array}$ & $\begin{array}{l}\text { Ration in } \\
\text { total (\%) }\end{array}$ & Total & Shoot & $\begin{array}{l}\text { Ration in total } \\
\text { plant (\%) }\end{array}$ & $\begin{array}{l}\text { Pod } \\
\text { wall }\end{array}$ & $\begin{array}{l}\text { Ration in total } \\
\text { plant }(\%)\end{array}$ & $\begin{array}{c}\text { Seeds per } \\
\text { plant }\end{array}$ & $\begin{array}{l}\text { Ration in total } \\
\text { plant }(\%)\end{array}$ & Total \\
\hline \multicolumn{16}{|c|}{$2006-2007$} \\
\hline Control & $1537 b$ & $4282 d$ & 69 & $1237 \mathrm{a}$ & 20 & $667 a$ & 11 & $6186 c$ & $2524 a$ & 55 & $536 a$ & 12 & $1490 a$ & 33 & $4550 \mathrm{a}$ \\
\hline 20 & $1578 b$ & $4478 c$ & 77 & $799 \mathrm{c}$ & 14 & $561 b$ & 10 & $5838 \mathrm{~d}$ & $1908 \mathrm{~b}$ & 50 & $512 \mathrm{~b}$ & 13 & $1380 \mathrm{~b}$ & 36 & $3800 \mathrm{~b}$ \\
\hline 40 & $2135 a$ & $5756 a$ & 77 & $1120 \mathrm{~b}$ & 15 & $646 a$ & 9 & $7522 \mathrm{a}$ & $2553 a$ & 68 & $272 c$ & 7 & $911 \mathrm{c}$ & 24 & $3736 \mathrm{~b}$ \\
\hline 60 & $1464 c$ & $5659 \mathrm{~b}$ & 84 & $668 \mathrm{~d}$ & 10 & $426 c$ & 6 & $6753 b$ & $2550 \mathrm{a}$ & 72 & $204 d$ & 6 & $769 \mathrm{~d}$ & 22 & $3523 \mathrm{c}$ \\
\hline
\end{tabular}

LSD $_{0.01}(\mathrm{~N})$ Shoot 34.69; Pod wall 15.55; Seed per plant 20.70

LSD $_{001}$ (G) Shoot 30.04; Pod wall 11.00; Seed per plant 14.63

$\mathrm{LSD}_{001}(\mathrm{~N} \times \mathrm{G})$ Shoot 60.09; Pod wall 22.00; Seed per plant 29.27

$\mathrm{LSD}_{001}(\mathrm{~N})$ Shoot 12.28; Pod wall 18.82; Seed per plant 0.12

$\mathrm{LSD}_{0.01}(\mathrm{G})$ Shoot 10.64; Pod wall 13.31; Seed per plant 0.09

$\mathrm{LSD}_{001}(\mathrm{~N} \times \mathrm{G})$ Shoot 21.28; Pod wall 26.62; Seed per plant 0.18

There is no difference in the same letter, ${ }^{1}$ stage of $\mathrm{V} 5$; $^{2}$ stage of R6; ${ }^{3}$ stage of R8 
Tab. 4. Nitrogen concentration $\left(\mathrm{mg} \mathrm{g}^{-1}\right)$ of shoot, pod wall and seed of lentil

\begin{tabular}{|c|c|c|c|c|c|c|c|}
\hline & Vegetative $^{1}$ & & d pod cavi & & & Maturity $^{3}$ & \\
\hline $\begin{array}{c}\mathrm{N} \text { rate } \\
\left(\mathrm{kg} \mathrm{ha}^{-1}\right)\end{array}$ & Shoot & Shoot & Pod wall & Seed & Shoot & Pod wall & Seed \\
\hline \multicolumn{8}{|c|}{$2006-2007$} \\
\hline Control & $31.93 \mathrm{c}$ & 15.80 & $16.50 \mathrm{~b}$ & $38.97 \mathrm{a}$ & $14.95 \mathrm{c}$ & $19.91 \mathrm{ab}$ & $30.53 b$ \\
\hline 20 & $32.35 \mathrm{ab}$ & 15.46 & $16.35 b$ & $41.37 \mathrm{a}$ & $14.72 \mathrm{c}$ & $14.78 \mathrm{c}$ & $38.25 \mathrm{a}$ \\
\hline 40 & $33.95 \mathrm{ab}$ & 15.92 & $20.27 \mathrm{a}$ & $33.74 b$ & $17.86 \mathrm{~b}$ & $17.50 \mathrm{bc}$ & $35.93 \mathrm{a}$ \\
\hline 60 & $34.92 \mathrm{a}$ & 16.51 & $19.48 \mathrm{ab}$ & $38.57 \mathrm{a}$ & $20.86 a$ & $21.25 \mathrm{a}$ & $39.50 \mathrm{a}$ \\
\hline \multicolumn{8}{|c|}{$\mathrm{LSD}_{0.01}$ (N) Shoot 1.51; Pod wall 2.40; Seed per plant 3.29} \\
\hline \multicolumn{8}{|c|}{$\mathrm{LSD}_{0.01}(\mathrm{G})$ Shoot 1.30; Pod wall 1.70; Seed per plant 2.33} \\
\hline \multicolumn{8}{|c|}{$\mathrm{LSD}_{001}(\mathrm{~N} \times \mathrm{G})$ Shoot 2.61; Pod wall 3.40; Seed per plant 4.66} \\
\hline \multicolumn{8}{|c|}{ 2007-2008 } \\
\hline Control & $35.00 \mathrm{~b}$ & 23.20 & 33.80 & $42.09 \mathrm{~b}$ & $26.24 \mathrm{a}$ & 24.82 & $37.72 b$ \\
\hline 20 & $38.76 \mathrm{a}$ & 24.54 & 38.78 & $41.47 \mathrm{c}$ & $22.55 b$ & 28.49 & $38.69 \mathrm{~b}$ \\
\hline 40 & $39.91 \mathrm{a}$ & 23.51 & 36.24 & $43.80 \mathrm{ab}$ & $25.38 \mathrm{ab}$ & 24.10 & $37.22 b$ \\
\hline 60 & $37.85 a$ & 23.77 & 39.05 & $43.93 \mathrm{a}$ & $24.14 \mathrm{ab}$ & 29.36 & $41.42 \mathrm{a}$ \\
\hline \multicolumn{8}{|c|}{$\mathrm{LSD}_{0.01}(\mathrm{~N})$ Shoot 1.51; Pod wall 2.16; Seed per plant 1.28} \\
\hline \multicolumn{8}{|c|}{$\mathrm{LSD}_{0.01}(\mathrm{G})$ Shoot 1.42; Pod wall 1.53; Seed per plant 0.91} \\
\hline \multicolumn{8}{|c|}{$\mathrm{LSD}_{001}(\mathrm{~N} \times \mathrm{G})$ Shoot 2.84; Pod wall 3.05; Seed per plant 1.81} \\
\hline
\end{tabular}

${ }^{1}$ stage of V5; ${ }^{2}$ stage of R6; ${ }^{3}$ stage of R8

mulation of $\mathrm{N}$ and, therefore, driving the great difference found between the years. The highest total $\mathrm{N}$ accumulation was found at R6 and decreased throughout maturity in both of the years. The highest total $\mathrm{N}$ accumulation occurred at $\mathrm{R} 6$ under $60 \mathrm{~kg} \mathrm{~N} \mathrm{ha}^{-1}$ in the second year, indicating that $54 \%$ of the $\mathrm{N}$ accumulation occurred in the shoot and the remaining $\mathrm{N}$ was allocated to the pod wall (24\%) and seed (22\%). However, the highest total $\mathrm{N}$ accumulation at maturity was $33 \%$ in the shoot, and the remaining $\mathrm{N}$ was allocated to the pod wall (14\%) and seed (53\%). As has been previously reported, $\mathrm{N}$ accumulation seems to depend upon the needs of the plant rather than being determined by the $\mathrm{N}$ concentration in the rooting medium. Indeed, rates of $\mathrm{N}$ acquisition seem to be controlled by specific demand-driven regulatory mechanisms (Schiltz et al., 2005).

Pengelly et al. (1999) and Soltani et al. (2006) reported that the highest proportion of $\mathrm{N}$ accumulation was partitioned to the stem and the leaves at the seed-filling stage. A decrease in the $\mathrm{N}$ level over the crop growth period has been reported in both crops and isolated plants (Gastal and Lemaire, 2002; Jeuffroy et al., 2002; Soltani et al., 2006). Two reasons have been given for the phenomenon. Firstly, the ratio of leaf (metabolic tissue with high $\mathrm{N}$ levels) to stem (structural tissue with low $\mathrm{N}$ levels) decreases during growth. Secondly, the $\mathrm{N}$ from the shaded (self and mutual) parts of the canopy is recycled, providing some of the $\mathrm{N}$ required for growth, thus decreasing the $\mathrm{N}$ uptake over time. Malhi et al. (2007) also found that there was a large decrease in the uptake of nutrients in lentil and pea plants between the grain-filling to harvest stages. These authors attributed a decreased nutrient uptake in the seed to a decreased translocation of nutrients from the vegetative to reproductive parts during the reproductive stages of the crops, although the decreased maximum nutrient uptake and decreased amount of nutrients at harvest may have also played a role in decreasing the nutrient uptake in the seeds at harvest.

Nitrogen accumulation at all growth stages was affected by the $\mathrm{N}$ fertiliser during the two years of the study. The nitrogen accumulation of the shoot in all of the growth stages was highest under an application of $40 \mathrm{~kg} \mathrm{~N} \mathrm{ha}^{-1}$ in the first year and under $20 \mathrm{~kg} \mathrm{~N} \mathrm{ha}^{-1}$ in the second year. Whereas the $\mathrm{N}$ accumulation decreased in the shoot and pod wall at harvest, it increased in the seed. The seed $\mathrm{N}$ accumulation at maturity was the highest under $20 \mathrm{~kg} \mathrm{~N} \mathrm{ha}^{-1}$ during the two years, and the $\mathrm{N}$ accumulation in the seed did not increase with the increasing $N$ rate. Similar effects of $\mathrm{N}$ fertiliser on nodulation and $\mathrm{N}$ fixation have been reported in studies of other legumes (Clayton et al., 2004; Walley et al., 2005). These results lead to the conclusion that when the conditions are favourable for nodulation and $\mathrm{N}$ fixation, the application of $\mathrm{N}$ fertiliser will partly replace the $\mathrm{N}$ from fixation without positively increasing the productivity of the plant. Moreover, the present findings for lentil are substantiated by those of El Mejahed (1993), who found that chickpea absorbed $18 \mathrm{~kg} \mathrm{~N} \mathrm{ha}^{-1}$ from the soil during a normal year, and Niri et al. (2010), who reported the highest nitrogen uptake occurred under $25 \mathrm{~kg} \mathrm{~N} \mathrm{ha}^{-1}$.

The relationship that exists between $\mathrm{N}$ and the plant development, dry matter, and $\mathrm{N}$ accumulation in lentil plants grown under rain-fed conditions showed that the dry matter accumulation of the shoot varied according to the growth stages and that a maximum biomass amount accumulated at R6. The maximum biomass accumulation and $\mathrm{N}$ accumulation at harvest were lower in the first year in comparison to the second year, a finding that may be 
Tab. 5. Nitrogen accumulation (mg N/g dry matter) of shoot, pod wall and seed

\begin{tabular}{|c|c|c|c|c|c|c|c|c|c|c|c|c|c|c|c|}
\hline \multicolumn{3}{|c|}{ Vegetative $^{1}$} & \multicolumn{5}{|c|}{ Filled pod cavities ${ }^{2}$} & & \multicolumn{7}{|c|}{ Maturity $^{3}$} \\
\hline $\begin{array}{l}\text { N rate } \\
\left(\mathrm{kg} \mathrm{ha}^{-1}\right)\end{array}$ & Shoot & Shoot & $\begin{array}{l}\text { Ration in } \\
\text { total (\%) }\end{array}$ & $\begin{array}{l}\text { Pod } \\
\text { wall }\end{array}$ & $\begin{array}{l}\text { Ration in } \\
\text { total (\%) }\end{array}$ & $\begin{array}{l}\text { Seeds per } \\
\text { plant }\end{array}$ & $\begin{array}{l}\text { Ration in } \\
\text { total (\%) }\end{array}$ & Total & Shoot & $\begin{array}{l}\text { Ration in } \\
\text { total }(\%)\end{array}$ & $\begin{array}{l}\text { Pod } \\
\text { wall }\end{array}$ & $\begin{array}{l}\text { Ration in } \\
\text { total (\%) }\end{array}$ & $\begin{array}{c}\text { Seeds per } \\
\text { plant }\end{array}$ & $\begin{array}{l}\text { Ration in } \\
\text { total (\%) }\end{array}$ & Total \\
\hline \multicolumn{16}{|c|}{$2006-2007$} \\
\hline Control & $49.09 \mathrm{~b}$ & $67.65 b$ & 59 & $20.42 b$ & 18 & $25.98 \mathrm{a}$ & 23 & 114.05 & $37.74 \mathrm{c}$ & 40 & $10.68 \mathrm{a}$ & 11 & $45.49 \mathrm{~b}$ & 48 & 93.91 \\
\hline 20 & $51.06 \mathrm{~b}$ & $69.24 \mathrm{~b}$ & 66 & $13.07 \mathrm{c}$ & 12 & $23.21 \mathrm{a}$ & 22 & 105.52 & $28.08 \mathrm{~d}$ & 32 & $7.56 \mathrm{~b}$ & 9 & $52.72 \mathrm{a}$ & 60 & 88.36 \\
\hline 40 & $72.50 \mathrm{a}$ & $91.63 \mathrm{a}$ & 67 & $22.71 \mathrm{a}$ & 17 & $21.79 \mathrm{ab}$ & 16 & 136.13 & $45.60 \mathrm{~b}$ & 55 & $4.76 c$ & 6 & $32.74 \mathrm{c}$ & 39 & 83.10 \\
\hline 60 & $51.12 b$ & $93.42 \mathrm{a}$ & 76 & $13.00 \mathrm{c}$ & 11 & $16.45 \mathrm{c}$ & 13 & 122.87 & $53.18 \mathrm{a}$ & 60 & $4.34 c$ & 5 & $30.39 \mathrm{c}$ & 35 & 87.91 \\
\hline
\end{tabular}

LSD $_{0.01}(\mathrm{~N})$ Shoot 4.39; Pod wall 1.52; Seed per plant 4.47

LSD $_{0.11}(G)$ Shoot 3.80; Pod wall 1.08; Seed per plant 3.16

$\mathrm{LSD}_{001}(\mathrm{~N} \times \mathrm{G})$ Shoot 7.60; Pod wall 2.16; Seed per plant 6.33

\begin{tabular}{|c|c|c|c|c|c|c|c|c|c|c|c|c|c|c|c|}
\hline \multicolumn{16}{|c|}{$2007-2008$} \\
\hline Control & $69.10 \mathrm{~b}$ & $109.34 \mathrm{~d}$ & 52 & $54.86 \mathrm{~b}$ & 26 & $46.01 c$ & 22 & 210.21 & $85.07 \mathrm{a}$ & 43 & $21.83 \mathrm{~b}$ & 11 & $92.15 b$ & 46 & 199.05 \\
\hline 20 & $99.64 a$ & $153.42 \mathrm{a}$ & 60 & $52.06 \mathrm{~b}$ & 20 & $48.83 c$ & 19 & 254.31 & $70.06 \mathrm{~b}$ & 33 & $30.61 \mathrm{a}$ & 14 & $112.08 \mathrm{a}$ & 53 & 212.75 \\
\hline 40 & $95.41 \mathrm{a}$ & $126.28 \mathrm{c}$ & 49 & $64.19 a$ & 25 & $67.10 \mathrm{a}$ & 26 & 257.57 & $72.56 \mathrm{~b}$ & 43 & $15.54 \mathrm{c}$ & 9 & $80.40 \mathrm{c}$ & 48 & 168.50 \\
\hline 60 & $70.05 \mathrm{~b}$ & $141.70 \mathrm{~b}$ & 54 & $62.27 \mathrm{a}$ & 24 & $55.93 \mathrm{~b}$ & 22 & 259.90 & $72.63 \mathrm{~b}$ & 39 & $16.70 \mathrm{c}$ & 9 & $95.14 \mathrm{~b}$ & 52 & 184.47 \\
\hline
\end{tabular}

LSD $(\mathrm{N})$ Shoot 5.72; Pod wall 2.76; Seed per plant 2.94

LSD $_{0.01}(\mathrm{G})$ Shoot 4.95; Pod wall 1.95; Seed per plant 2.08

LSD $_{001}(\mathrm{~N} \times \mathrm{G})$ Shoot 9.91; Pod wall 3.91; Seed per plant 4.16

'stage of V5; ${ }^{2}$ stage of R6; 'stage of R8 
202

explained by the variation in the weather conditions between the years. Overall, the findings suggest that a sufficient supply of nutrients for high levels of biomass accumulation and $\mathrm{N}$ accumulation at early growth stages and the translocation of the biomass and $\mathrm{N}$ to the seed at later growth stages are of great importance for high yields in lentil. Nitrogen fertiliser had a positive effect on the seed weight and $\mathrm{N}$ accumulation in lentil. In conclusion, it is suggested that $20 \mathrm{~kg} \mathrm{~N}^{-1}{ }^{-1}$ will increase the per-plant dry matter and $\mathrm{N}$ accumulation of the seeds under rain-fed conditions.

\section{Acknowledgments}

This research was supported in part by Eskisehir Osmangazi University Research Foundation (Project no: 200623033).

\section{References}

Beck DP, Wery J, Saxena MC, Ayadi A (1991). Dinitrogen fixation and nitrogen balance in cool-season food legumes. Agron J 83:334-341.

Caliskan S, Ozkaya I, Caliskan ME, Arslan M (2008). The effects of nitrogen and iron fertilization on growth, yield and fertilizer use efficiency of soybean in a Mediterraneantype soil. Field Crops Res 108:126-132.

Casa R, Russell G, Lo Cascio B, Rossini F (1999). Environmental effects on linseed (Linum usitatissimum $\mathrm{L}$ ) yield and growth of flax at different stand densities. Eur J Agron 11:267-278.

Clayton GW, Rice WA, Lupwayi NZ, Johnston AM, Lafond GP, Grant CA, Walley F (2004). Inoculant formulation and fertilizer nitrogen effects on field pea: nodulation, $\mathrm{N}_{2}$ fixation and nitrogen partitioning. Can J Plant Sci 84:7988.

Diepenbrock WA, Léon J, Clasen K (1995). Yielding ability and yield stability of linseed in Central Europe. Agron J 87:8488.

Dordas C, Sioulas C (2009). Dry matter and nitrogen accumulation, partitioning, and retranslocation in safflower (Carthamus tinctorius $\mathrm{L}$ ) as affected by nitrogen fertilization. Field Crops Res 110:35-43.

El Mejahed K (1993). Effect of N on yield, N uptake and water use efficiency of wheat in rotation systems under semiarid conditions of Morocco University Microfilms International. http://digitalcommonsunledu/dissertations/AAI9415960.

Erskine W, Muehlbauer FJ, Short RW (1990). Stages of development in lentil. Exp Agr 26:297-302.

Gastal F, Lemaire G (2002). Nitrogen uptake and distribution in crops: an agronomical and ecophysiological perspective. J Exp Bot 53:789-799.

Hayati R, Egli DB, Crafts-Brandner SJ (1995). Carbon and nitrogen supply during seed filling and leaf senescence in soybean. Crop Sci 35:1063-1069.

Jeuffroy MH, Ney B, Qurry A (2002). Integrated physiological and agronomic modeling of $\mathrm{N}$ capture and use within the plant. J Exp Bot 53:809-823.
Lhuillier-Soundele A, Munier-Jolain NG, Ney B (1999). Dependence of seed nitrogen concentration on plant nitrogen availability during the seed filling in pea. Eur J Agron 11:157-166.

Malhi SS, Johnston AM, Schoenau JJ, Wang ZH, Vera CL (2007). Seasonal biomass accumulation and nutrient uptake of pea and lentil on a black chernozem soil in Saskatchewan. J Plant Nutr 30:721-737.

Marschner H (1995). Mineral nutrition of higher plants, Ed 2 Academic Press, London.

McNeil DL, Materne M (2007) Rhizobium management and nitrogen fixation lentil, 127-143 p. In: Yadav SS (Ed.). An ancient crop for modern times.

Muchow RC, Robertson, MJ, Pengelly, BC (1993). Accumulation and partitioning of biomass and nitrogen by soybean, mungbean and cowpea under contrasting environmental conditions. Field Crops Res 33:13-36.

Niri HH, Tobeh A, Gholipouri A, Mostafaei H, Jamaati-eSomarin $S$ (2010). Effect of nitrogen and phosphorous rates on fertilizer use efficiency in lentil. World Appl Sci J 9:10431046.

Papakosta DK, Gagianas AA (1991). Nitrogen and dry matter accumulation, remobilization and losses for Mediterranean wheat during grain filling. Agron J 83:864-870.

Pengelly BC, Blamey FPC, Muchow RC (1999). Radiation interception and the accumulation of biomass and nitrogen by soybean and three tropical annual forage legumes. Field Crops Res 63:99-112.

Saxena NP (1984) Chickpea, 207-232 p. In: Goldsworthy PR, Fisher NM (Eds.). The physiology of tropical field crops, Wiley, New York.

Schiltz S, Munier-Jolain N, Jeudy C, Burstin J, Salon C (2005). Dynamics of exogenous nitrogen partitioning and nitrogen remobilization from vegetative organs in pea revealed by ${ }^{15} \mathrm{~N}$ in vivo labeling throughout seed filling. Plant Physiol 137:1463-1473.

Soltani A, Hammer GL, Torabi B, Robertson MJ, Zeinali E (2006). Modeling chickpea growth and development: Nitrogen accumulation and use. Field Crops Res 99:24-34.

Togay Y, Togay N, Doğan Y, Çiftçi V (2005). Effects of nitrogen levels and forms on the yield and yield components of lentil (Lens culinaris Medik). Asian J Plant Sci 4:64-66.

Turpin JE, Robertson MJ, Hillcoat NS, Herridge DF (2002). Faba bean (Vicia faba) in Australia's northern grains belt: canopy development, biomass, and nitrogen accumulation and partitioning. Aust J Agric Res 53:227-237.

van Kessel C, Hartley C (2000). Agricultural management of grain legumes: has it led to an increase in nitrogen fixation? Field Crops Res 65:165-181.

Walley FL, Kyei-Boahen S, Hnatowich G Stevenson C (2005). Nitrogen and phosphorus fertility management for desi and kabuli chickpea. Can J Plant Sci 85:73-79.

Whitehead SJ, Summerfield RJ, Muehlbauer FJ, Coyne, CJ, Ellis RH, Wheeler TR (2000) Crop improvement and the accumulation and partitioning of biomass and nitrogen in lentil. Crop Sci 40:110-120. 